\title{
Antioxidant Activity of Methanol Extract/Fractions of Senggani Leaves (Melastoma candidum D. Don)
}

\author{
Marjoni MR* and Zulfisa A
}

Pharmacy Academy of Dwi Farma Bukittinggi, Bukittinggi 26121, West Sumatera, Indonesia

*Corresponding author: Marjoni MR, Pharmacy Academy of Dwi Farma Bukittinggi, Bukittinggi 26121, West Sumatera, Indonesia, Tel: +62-752-625164; Fax: +62-752-625164; E-mail: mhdriza.marjoni@gmail.com

Received date: Jun 10, 2017; Accepted date: July 31, 2017; Published date: August 04, 2017

Copyright: ( 2017 Marjoni MR, et al. This is an open-access article distributed under the terms of the Creative Commons Attribution License, which permits unrestricted use, distribution, and reproduction in any medium, provided the original author and source are credited.

\begin{abstract}
Senggani (Melastoma candidum D. Don) leafis one of many plants in hilly areas around the city of Bukittinggi and one of biological potencies that can be utilized primarily as antioxidant and used to treat various diseases. Some active compounds in Melastoma genus that has activity as an antioxidant such as flavonoids and tannins.

This study aims to examine the activity of free radical scavenging by methanol extract of senggani leaves and their fractions. The antioxidant activity of methanol extract of senggani leaves and its fractions was evaluated in vitro assays using the 2,2-diphenyl-1-picrilhidrazine (DPPH) method. The amount of antioxidant activity is characterized by the value of IC50 which is concentration of extract and fractions required to inhibit $50 \%$ of DPPH free radicals. The results showed that the antioxidant activity of senggani leaves were very strong for ethyl acetate and chloroform fractions with IC50 valuesof $43,1301 \mu \mathrm{g} / \mathrm{ml}$ and $43,8924 \mu \mathrm{g} / \mathrm{ml}$, respectively, while for methanol fraction was strong with IC50 value of $65,6521 \mu \mathrm{g} / \mathrm{ml}$. While the fraction of $\mathrm{n}$ hexane was categorized moderate with IC50 value of $122,3880 \mu \mathrm{g} / \mathrm{ml}$. Senggani leaves have potential to be used as natural antioxidant in preventing free radicals.
\end{abstract}

Keywords: Melastoma candidum D. Don; Antioxidant; Fractionation; DPPH

\section{Introduction}

Free radicals are atoms, groupsof atoms or molecules that have one or more unpaired electrons in the outermost orbital, so they are chemically highly reactive and tend to seek electron pairs to be able to bind to achieve stability. Free radical atoms are constantly attacking body's cells including normal cells for obtaining electron pairs $[1,2]$. Free radicals react with biological compounds in body continuously and if they do not stop, they can damage body cells and provides harmful effects to body health. This free radical reaction will also cause various diseases such as cancer, heart, cataract, premature aging, and other degenerative diseases [3].

Based on the source, free radicals can be sourced from outside body such as motor vehicle pollution, cigarette smoke, and ultraviolet light. In addition, free radicals can also come from within body it selfie during the process of respiration, oxidative enzyme, as well as oxidative phosphorylation in mitochondria. Thus, even if we avoid free radicals from outside the body, free radicals will automatically be generated from normal biological processes of body. To overcome this, antidote of free radicals or antioxidants are needed that serve to inhibit or stop the negative effects caused by free radicals $[4,5]$.

Secondary metabolite compounds derived from plants, especially phenolic compounds has potential to be natural antioxidants. Many studies suggest that phenolic group compounds such as flavonoids, phenolic acids, lignins, cinnamic acids, coumarins, tocopherols and tannins have their activities as natural antioxidants [6]. Antioxidants derived from plants are highly recommended in this case, they are safer for body and can block oxidative damage through reduction with free radicals, forming chelates with catalytic metal compounds, and capturing oxygen [7].

One of the plants that have potential to be developed as natural antioxidant is senggani leaves (Melastoma candidum D. Don). The preliminary test showed that the extract of senggani leaves contains phenolic compounds and strong antioxidant activity. Based on the result, this study was conducted, with the aim to determine the antioxidant activity of methanol extract of senggani leaves and its fractions.

\section{Materials and Methods}

\section{Research methodology}

The research method used is explanatory research approached by regression analysis. Explanatory research is a study conducted to determine the value of independent variables, either one or more (independent) variables without making a comparison, or relate with other variables [8].

\section{Materials}

Senggani leaves used were taken from Panta Sub Regency, Agam Province of West Sumatra Indonesia. Sampling was done purposively i.e., without comparing with other regions. Chemicals: ethanol (E. Merck), n-hexane (E. Merck), ethyl acetate (E. Merck), chloroform (E. Merck) and aquadest. The material for the radical scavenging 2,2Diphenyl-1-Pikrilhidrazil (DPPH) (Sigma. Co.). 
Page 2 of 6

\section{Extraction and fractionation}

$250 \mathrm{~g}$ of fresh senggani leaves were macerated with methanol p.a for $3 \times 3$ days at room temperature. The maceration results were then filtered using Whatman no 1 filter paper. The filtrate was concentrated using rotary evaporator, to obtain a pourable extract. The methanol extract (partially) was added with aquadest in volume ratio of 2: 1 and parted liquid-liquid in the Liquid-Liquid Continuous Extraction (LLCE) appliance using $\mathrm{n}$-hexane, chloroform and ethylacetate solvents in volume ratio of $1: 3$. The extract of the fractionation was concentrated with rotary evaporator to obtain thick extension of each fraction.

\section{DPPH radical scavenging activity}

In this method, activity of free radical scavenging extract or fractions is determined by measuring the intensity of the purple color from the DPPH methanol solution [9].

Each extract and fraction was weighed $10 \mathrm{mg}$ then dissolved with methanol up to $10 \mathrm{ml}$, so we got concentration of $1 \mathrm{mg} / \mathrm{ml}$. Then dilution was performed by adding aquadest so that the samples with concentrations of $(10,30,50,70,90 \mu \mathrm{g} / \mathrm{ml})$ were obtained.

For the determination of antioxidant activity, each concentrate was pipetted of $0.2 \mathrm{ml}$ with a micro pipette inserted into vial, added $3.8 \mathrm{ml}$ of $50 \mu \mathrm{M}$ DPPH solution. The mixture was homogenized and left for $30 \mathrm{~min}$ in darkness, measured the absorption with a UV-Vis spectrophotometer at $514 \mathrm{~nm}$. The antioxidant activity of the samples was determined by the amount of DPPH radical absorption resistance by calculating the percentage of DPPH absorption inhibition using the formula:

Where, Ao: DPPH radical absorption of $50 \mu \mathrm{M}$ at $514 \mathrm{~nm}$ wavelength; As: Samples absorptions in DPPH radical of $50 \mu \mathrm{M}$ at 514 nm wavelength.

IC50 values of each extract and fractions concentrations were calculated using the linear regression formula.

\section{Results and Discussion}

The extraction of senggani leaves was performed using maceration method with ethanol solvent. This maceration method was chosen because the process is easy and does not require high temperature so it can reduce the possibility of damage to chemical compounds that have antioxidant activity contained in senggani leaves $[10,11]$.

Maseration results in the form of brownish green maceration were then concentrated using a rotary evaporator equipped with a vacuum pump. The vacuum process occurred during the evaporation of solvents which allowed the solvent to evaporate at temperature below its boiling point and the process of work can take place more quickly. Evaporation of methanol solvent can be carried out below its boiling point at $55^{\circ} \mathrm{C}$. This process was carried out at these temperatures to keep the active compounds contained undamaged by heating.

Senggani leaves are macerated with methanol for $3 \times 3$ days. The obtained macerate evaporated using a rotary evaporator to obtain viscous methanol extract. The viscous methanol extract was taken as much as $20 \mathrm{~g}$ of diffraction with solvents with increasing polarity starting from $n$-hexane, chloroform and ethyl acetate. Each fraction then evaporated with a rotary evaporator to obtain the viscous extract from each fraction.
The first fractionation was made using $\mathrm{n}$-hexane solvent. The $\mathrm{n}$ hexane solvent is non-polar so that it removes fat and attracts nonpolar compounds such as fatty acids, sterols, coumarins, and some terpenoids. This is followed by chloroform and ethyl acetate. Ethyl acetate is used to extract compounds with intermediate polarities such as flavonoids, tannins and some alkaloids. The viscous methanol extract which is more polar than other solvents was used to extract polar compounds such as flavonoids, glycosides, tannins, and some alkaloids [12].

Screening of phytochemical extract was performed by using tube test i.e., reacting the sample with specific reagent solution to find out the secondary metabolite content. Table 1 shows phytochemical screening results of senggani leaves.

\begin{tabular}{|l|l|l|l|}
\hline S. No. & Secondary Metabolite & Reactor & Description \\
\hline 1 & Alkaloids & Mayer \& Dragendorff & \\
\hline 2 & Flavonoids & $\mathrm{HCL}$ and $\mathrm{Mg}$ & + \\
\hline 3 & Tanin & $\mathrm{FeCl}_{3}$ & + \\
\hline 4 & Phenolic & $\mathrm{FeCl}_{3}$ & + \\
\hline 5 & Saponin & Aquades & + \\
\hline 6 & Glycosides & Lieberman-Burchad & + \\
\hline
\end{tabular}

Table 1: Phytochemical screening results.

Based on the results of phytochemical screening examination, it was known that methanol extract of senggani leaves has secondary metabolite namely flavonoida, phenolic, saponin, tannin, and glikosida compounds.

The antioxidant activity of each extract and fraction was performed using DPPH method. This method is a common and simple method used to test antioxidant activity in vitro. According to Hanani in 2005 the DPPH free radical absorption method is a simple, easy and can be done using a small amount of sample and a relatively short working time [13]. In addition to the simplicity of the method, this DPPH method requires few samples and chemicals and takes time not too long. Measurement of antioxidant activity was performed using UV-vis spectrophotometer at a maximum DPPH wavelength of $514 \mathrm{~nm}$ which is the maximum DPPH wavelength at a concentration of $50 \mu \mathrm{M}$. The presence of antioxidant activity from the sample resulted in a change of color of the original DPPH solution which initially in viscous purple (violet) into pale yellow [14]. The antioxidant activity of each fraction is also carried out at the same wavelength.

The principle of DPPH method is the antioxidant interaction with DPPH as free radical both by electron transfer or hydrogen radical at DPPH and will neutralize free radical from DPPH. Free radicals are highly reactive molecules because they have unpaired electrons in their outer orbitals that can react with cellular molecules by binding to cell's electrons, resulting in a chain reaction that produces new free radicals [15].

If all the electrons in DPPH free radicals become paired then color of the solution would change from dark purple to bright yellow and the absorbance measured at $514 \mathrm{~nm}$ wavelength $[16,17]$. The absorbance measurements were performed after incubation for $30 \mathrm{~min}$ to allow the reaction between DPPH as free radical and the tested samples. The determination of antioxidant activity values is performed 
quantitatively by measuring the activity of DPPH radical capture by a compound having antioxidant activity using UV-vis spectrophotometry. The result of spectrophotometer measurement is UV-Vis spectra at visible wavelength range.

The results of this study indicate the presence of antioxidant activity seen from the decrease of absorption values of DPPH radical caused by the test samples at various concentrations and the increasing value of the percentage of inhibition produced. The change in color of DPPH from purple to a slightly yellowish after $30 \mathrm{~min}$ incubated was visible and can also be observed. This DPPH color change is caused by the presence of compounds in the sample used to donate its hydrogen atom to free radical of DPPH, so reducing it to a more stable form of DPPH-H (1,1-diphenyl-2-picrylhydrazine). From the measurements of methanol extract and fractions of senggani leaves of, it showed that the higher concentration used, the lower absorbance value obtained.

The reaction scheme between free radicals and antioxidants can be seen by the following Figure 1 .

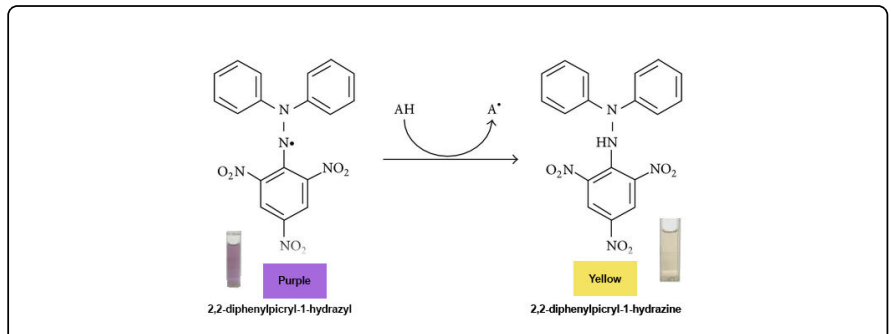

Figure 1: Schematic of the reaction between free radicals and antioxidants.

The determination results of antioxidant activity of senggani leaves extract and can be seen in Table 2 .

\begin{tabular}{|c|c|c|c|c|}
\hline $\begin{array}{ll}\text { Extract } & \text { and } \\
\text { Fractions } & \end{array}$ & Concentration $(\mu \mathrm{g} / \mathrm{ml})$ & Inhibition average ( \% ) & Linear Regression Equation & IC50 \\
\hline \multirow{5}{*}{ Methanol } & 5 & 32.317 & \multirow{5}{*}{$\hat{y}=0.299 x+30.37$} & \multirow{5}{*}{$65,6521 \mu \mathrm{g} / \mathrm{ml}$} \\
\hline & 15 & 34.603 & & \\
\hline & 25 & 37.079 & & \\
\hline & 35 & 41.46 & & \\
\hline & 45 & 43.873 & & \\
\hline \multirow{5}{*}{ Chloroform } & 5 & 26,98 & \multirow{5}{*}{$\hat{y}=23,9235+0,5941 x$} & \multirow{5}{*}{$43,8924 \mu \mathrm{g} / \mathrm{ml}$} \\
\hline & 15 & 32,57 & & \\
\hline & 25 & 38,54 & & \\
\hline & 35 & 45,64 & & \\
\hline & 45 & 50,15 & & \\
\hline \multirow{5}{*}{ Ethyl Acetate } & 5 & 35.81 & \multirow{5}{*}{$\hat{y}=0.361 x+34.43$} & \multirow{5}{*}{$43,1301 \mu \mathrm{g} / \mathrm{ml}$} \\
\hline & 15 & 40.635 & & \\
\hline & 25 & 43.556 & & \\
\hline & 35 & 46.286 & & \\
\hline & 45 & 51.048 & & \\
\hline \multirow{5}{*}{ N Hexana } & 5 & 0.762 & \multirow{5}{*}{$\hat{y}=0.420 x-1.403$} & \multirow{5}{*}{$122,3880 \mu \mathrm{g} / \mathrm{m}$} \\
\hline & 15 & 5.079 & & \\
\hline & 25 & 8.952 & & \\
\hline & 35 & 12.825 & & \\
\hline & 45 & 17.905 & & \\
\hline
\end{tabular}

Table 2: Antioxidant activity of senggani leaves extract and fractions.

According to Sudjana [8], the linear regression equation has positive $b$ value, thus indicating that the curve of antioxidant inhibition values is an increasing curve. The coefficient $b$ is the linear regression coefficient and denotes that the average change of $y$ variable for each variable change is by one unit. From the data on the methanol fraction, we got the value of $b=+30.37$, so it can be said that for every $x$ (sample concentration) increased $\mathrm{BH} 1 \mu \mathrm{g} / \mathrm{ml}$, then y (\% inhibition) increased by 0.299 . 
Charts of antioxidant activity measurements of extract and fractions are shown in Figure 2.

(a)

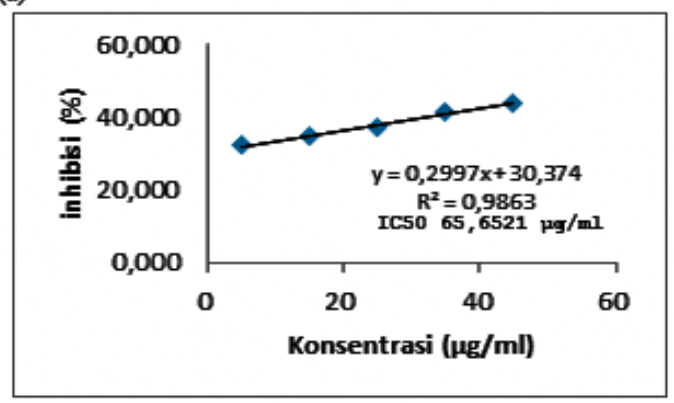

(c)

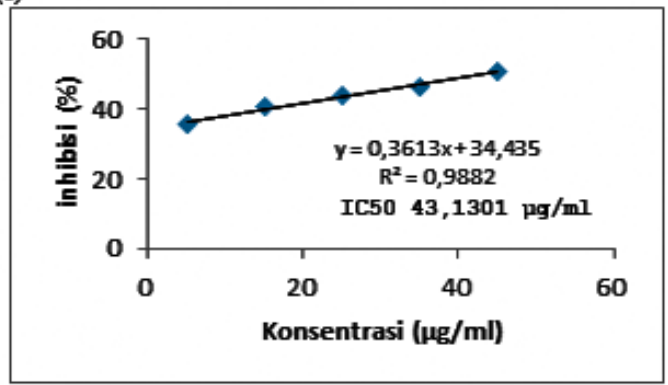

(b)

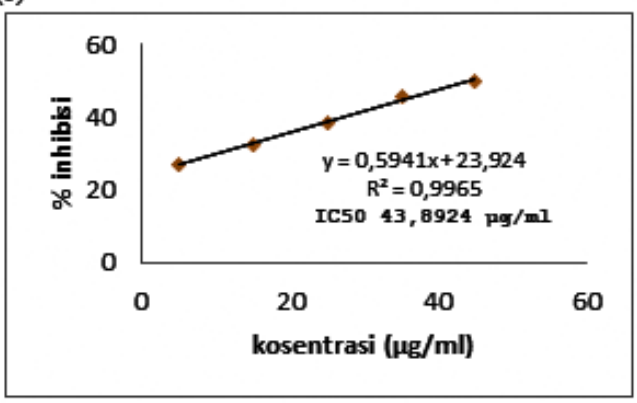

(d)

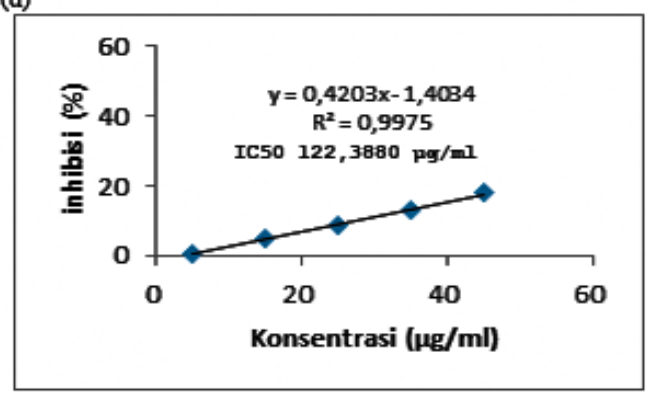

Figure 2: IC50 values obtained based on linear regression equation for (a) Methanol (b) Chloroform (c) Ethyl acetate and (d) N hexane fractions.

The regression curve also shows that there is a close correlation between concentration and\% inhibition. This is shown by the values of $\mathrm{R}$ (correlation coefficient), and $\mathrm{R} 2$ (coefficient of determination) above 0.90 . The values of $\mathrm{R}$ indicate that there is a correlation between the samples concentrations and\% inhibition. From the values of R2 ( R square) it can be seen that there is a significant correlation between the concentration of solvent with\% inhibition observed with the degree of closeness of $0,0.986$. This indicates that more than $98 \%$ of inhibition degree is affected by the concentration of the ingredients, while less than $2 \%$ is affected by other factors.

The result of methanol fraction test shows that the higher the solvent concentration, the higher the percentage of inhibition, this is due to the more samples, the higher the antioxidant content so that it also affects the level of free radical inhibition by the antioxidant agent.

The results of antioxidant activity test of Chloroform fraction by linear regression equation also has positive $b$ value, thus indicating that curve of antioxidant inhibition value at chloroform fraction also is an increasing curve. From the data seen on the fraction of chloroform, the value obtained of $b=+23,9235$ so, it can be said for every $\mathrm{x}$ (samples concentrations) increased by $1 \mu \mathrm{g} / \mathrm{ml}$, then $\mathrm{y}$ (\% inhibition) increased by 0.5941 .

So also with the antioxidant activity test of Ethyl Acetate Fraction, the data of linear regression equation also has positive $b$ value, thus indicating that the curve of antioxidant inhibition values on the ethanol fraction is also an increasing curve. From the data seen in the methanol fraction, we get the value of $b=+34.43$, so it can be said that for every x (samples concentrations) increases by $1 \mu \mathrm{g} / \mathrm{ml}$, then $\mathrm{y}(\%$ inhibition) increases by 0.361 .

The regression curve also shows that there is a close correlation between concentrations and\% inhibition. This is shown by the values of $\mathrm{r}$ (correlation coefficient), and R2 (coefficient of determination) above 0.90 . The values of $r$ indicate that there is a correlation between the sample concentrations with \% inhibition. From the values of R2 ( R square) it can be seen that there is a significant correlation between the concentration of solvent with \% inhibition observed with the degree of closeness of 0.988 . The test results show that the higher of the solvent concentration, the higher of the percentage of inhibition, this is due to the more samples, the higher the antioxidant content so that it also affects the level of free radical inhibition by the antioxidant agent

The parameter used to show the antioxidant activity is the values of inhibition concentration (IC50) which is the concentration of antioxidant substances that can reduce $50 \%$ of free radicals. According to Jun et.al 2003, antioxidant activity is classified into 5 groups: highly active, active, moderate, weak and inactive. For more detail can be seen in the Table 3. 
Page 5 of 6

\begin{tabular}{|l|l|l|}
\hline S. No. & Intensity & IC $_{\mathrm{s}}$ Values \\
\hline 1 & Highly active & $<50 \mu \mathrm{g} / \mathrm{ml}$ \\
\hline 2 & Active & $50-100 \mu \mathrm{g} / \mathrm{ml}$ \\
\hline 3 & Moderate & $101-250 \mu \mathrm{g} / \mathrm{ml}$ \\
\hline 4 & Weak & $250-500 \mu \mathrm{gg} / \mathrm{ml}$ \\
\hline 5 & Inactive & $>500 \mu \mathrm{g} / \mathrm{ml}$ \\
\hline
\end{tabular}

Table 3: Power levels of antioxidant by DPPH method [18].

Meanwhile, according to Molyneux, IC50 value of 200-1000 $\mu \mathrm{g} / \mathrm{ml}$ was declared less active but still has potential as an antioxidant [19]. Based on the results of the research, IC50 ethanol extract value is 5.030 $\mu \mathrm{g} / \mathrm{ml}$ so it falls into a very strong antioxidant category based on the average mean of IC50 indicated in Table 1, it is known that IC50 values obtained show that methanol extract and fractions of senggani leaves show the existence of antioxidant activity. The fractions of chloroform and ethyl acetate have very strong antioxidant activity because it has IC50 value less than $50 \mu \mathrm{g} / \mathrm{ml}$. A compound is said to be very active antioxidant if its IC50 value $<50 \mu \mathrm{g} / \mathrm{ml}$. The methanol fraction belongs to the active antioxidant category because it has IC50 value between $50-100 \mu \mathrm{g} / \mathrm{ml}(65.6521 \mu \mathrm{g} / \mathrm{ml})$. While for the $\mathrm{n}$-hexane fraction is included into weak antioxidant activity because a substance is said to have weak antioxidant activity when it has IC50 value of between $151-200 \mu \mathrm{g} / \mathrm{ml}$.

Based on IC50 values obtained, it is known that the fractions of ethyl acetate and chloroform have the greatest antioxidant activity. This is because the fractions of ethyl acetate and chloroform allegedly contain phenolic compound namely flavonoids in the form of aglicons, where the solubility of aglycons in flavonoids is found in the more nonpolar fraction. Possible antioxidant compounds of senggani leaves will potentially be antioxidants when extracted with semi-polar and non-polar solvents then flavonoid components attached to the glycine will be readily absorbed in a polar solvent such as water. This will lead to the occurrence of steric barriers that may inhibit reactions of free radical capturing and are less effective as antioxidants [20,21].

According to Gusrav, flavonoid compounds act as antioxidants because they have hydroxyl groups that can release protons in the form of hydrogen ions. The hydrogen ions only have one proton and do not have electrons, so in the radical electrons found on the nitrogen atoms in DPPH compound bound to hydrogen ions and produce reduced DPPH [22]. Radicals in DPPH can be reduced when reacting with a hydrogen donor contained in a phenolic compound [23].

The results of antioxidant extract test showed that antioxidant activity of Senggani leaves is very strong for ethyl acetate and chloroform fractions with the IC50 values of $43,1301 \mu \mathrm{g} / \mathrm{ml}$ and $43,8924 \mu \mathrm{g} / \mathrm{ml}$, respectively, while for methanol fraction is strong with IC50 value of $65,6521 \mu \mathrm{g} / \mathrm{ml}$. While the $\mathrm{n}$ hexane fraction categorized moderate with IC50 value of $122,3880 \mu \mathrm{g} / \mathrm{ml}$. The antioxidant potency of the less active $n$-hexane fraction is thought to be due to the presence of intruders such as proteins, fats and other soluble compounds in non-polar solvents, in this case n-hexane solvent, thereby blocking the free radical capturing process. The presence of protein or fat compounds in the fraction may interfere the free radical capturing process by flavonoid compounds. Protein or fats in plants can provide hydrogen atoms they possessed that will bind to the hydroxyl radicals in DPPH [24].

Ethyl acetate and chloroform fractions have very strong antioxidant activity because they contain more phenolic derivatives such as tannins and flavonoids. It is suspected that the classes of compounds that provide antioxidant activity in ethyl acetate and chloroform fractions are phenolic and flavonoids. Flavonoid compounds act as antioxidants because they have hydroxyl groups that can donate protons in the form of hydrogen ions. This hydrogen ion will bind to free radical electrons present in the nitrogen atoms of DPPH compound resulting in reduced DPPH [22].

\section{Conclusion}

Senggani leaves have a very powerful antioxidant activity. Fractions with antioxidant activity ranging from the strongest to the weakest are ethyl acetate fraction, chloroform fraction, methanol and $\mathrm{n}$ hexane fractions.

\section{References}

1. Donatus, IA (1994) Interaction of curcumin with paracetamol study on pharmacology aspects of biological change, dissertation, faculty of post graduate UGM, Yogyakarta.

2. Gitawati R (1995) Free radicals: Nature and role in making cell death. Mirror World Med 102: 33-35.

3. Kikuzaki H, Hisamoto M., Hirose K, Akiyama K, Taniguchi H (2002) Antioxidant properties of ferulic acid and its related compounds. J Agric Food Chem 50: 2161-2168.

4. Halliwel B, Gutteridge JMC (1992) Free radical in biology and medicine (3rd edn.). Oxford University Press, NY, USA pp: 796-798.

5. Lestariana W (2003) Biochemical reviews of diet to prevent disease deficiency and degenerative disease.

6. Kahkonen MP, Hopia AI, Fuorella HC (1999) Antioxidant activity of extract containing phenolic compound. J Agri Food Chem 47: 3954-3962.

7. Sayuti K, Yenrina R (2015) Antioxidants, natural and synthetic. Andalas University Press, Padang.

8. Sudjana (2002) Method of statistics. Tarsito: Bandung.

9. Abe N, Murata T, Hirota A (1998) Novel DPPH Radical Scavengers, Bisorbicillinol and Demethyltrichodimerol, from a Fungus Biosci Biotech Biochem 62: 661-666.

10. Ansel HC (2005) Introduction to pharmaceutical dosage form. Jakarta: UI Press, pp: 605-606, 608.

11. Voigt R (1995) Pharmacy technology, translated by Soendani NS, Yogyakarta. UGM Press, pp: 561; 567-569; 577.

12. Sarker, Satyajit D, Latif Z, Gray AI (2006) Natural products isolation. Totowa: Humana Press.

13. Hanani EA (2005) Identification of antioxidant compounds in sponges Callyspongia sp. from thousand islands. Pharmaceutical Science Magazine 2: 127-133.

14. Permana D, Hj Lajis N, Abas F, Ghafar Othman A, Ahmad R, et al. (2003) Antioxidative constituents of hedotis diffusa wild. Nat Pro Sci 9: 7-9.

15. Ketaren S (1986) Oil processing technology and food fat. UI-Press: Jakarta.

16. Green RJ (2004) Antioxidant activity of peanut plant tissues. North Caroline State University, Raleigh.

17. Gurav S, Deshkar N, Gulkari V, Duragkar N, Patil A (2007) Free radical scavengeng activity of polygala chinensis linn. Pharmacologyline 2: 245-253.

18. Jun M, Fu HY, Hong J, Wan X, Yang CS, et al. (2003) Comparison of antioxidant activities of isoflavones from kadzu root (puerari lobata ohwi). J Food Sci 68: 2117-2122.

19. Molyneux $P$ (2004) The use of the stable free radical diphenylpicrylhydrazyl for estimating antioxidant activity. SJST 26: 211-219. 
Citation: Marjoni MR, Zulfisa A (2017) Antioxidant Activity of Methanol Extract/Fractions of Senggani Leaves (Melastoma candidum D. Don). Pharm Anal Acta 8: 557. doi:10.4172/2153-2435.1000557

Page 6 of 6

20. Kahkonen MP, Hopia AI, Fuorella HC (1999) Antioxidant activity of extract containingphenolic compound. J Agri Food Chem 47: 3954-3962.

21. Pokorni J, Yanishlieva N, Gordon M (2001) An antioxidant in food practical application. Woddhead Publishing Ltd., England, pp: 2, 10-12, $17,44-45,101,107-108$.

22. Gusrav S, Deshkar N, Gulkari V, Duragkar N, Patil A (2007) Free radical scavenging activity of polygala chinensis linn. Pharmacology 2: 245-253
23. Arazo M, Bello A, Rastrelli L, Montelier M, Delgado L, et al. (2011) Antioxidant properties of pulp and peel of yellow mangosteen fruits. Emir J Food Agri 23: 517-524.

24. Pine HS (1988) Free radicals. Bandung: ITB. Organic Chemistry pp: 23-26. 